\title{
THE QUR'AN AND INDONESIAN COMMUNITY CULTURE: THE QUR'AN AS AN AMULET AMONG INDIGENOUS PEOPLE
}

\author{
Masri Mansoer \\ Syarif Hidayatullah State Islamic University (UIN) Jakarta \\ masri.mansoer@uinjkt.ac.id \\ Lilik Ummi Kaltsum \\ Syarif Hidayatullah State Islamic University (UIN) Jakarta \\ lilik.ummi@uinjkt.ac.id \\ Yadi Mulyadi \\ Syarif Hidayatullah State Islamic University (UIN) Jakarta \\ yadi.mulyadi15@mhs.uinjkt.ac.id
}

\begin{abstract}
Amulet or also known as talisman is a writing material or a spell that is believed to have a miracle and can be used as an antidote to a disease. Indigenous Peoples of Wewengkon Kasepuhan Citorek Lebak-Banten West Java is one of the Indonesian community who believes that the burden of everyday life will be reduced by wearing an amulet. The amulets are usually worn on the house walls, hang on the door, or used as a necklace. Besides amulets, Wewengkon society also practices a charming debus. Debus is an art of traditional practice staging remarkable human ability includes immunity to sharp weapon and fire resistance that is believed originally from the holy book of the Qur'an. This research is very interesting because, firstly, the majority of Indigenous people Wewengkon Kasepuhan Citorek Lebak-Banten is a Muslim; Secondly, the amulet use a few verses in the Qur'an or hijaiyyah (Quranic alphabets). This research includes a living Qur'an study as an effort of certain communities to revive the Qur'an in their daily life. Using the anthropological and ethnographic approach, this study has revealed; first, the belief in the amulet is originated from the belief of the elders or the respected one who ordered the use of amulets in daily life. Second, the verses written in the amulet are the verses of the Quran, al-muqaththa'ah and hijaiyyah alphabet; Third, the amulets are usually used in wallets, belts or the main door of the house; Fourth, a beneficial direct result of the amulets can be felt by indigenous people of Wewengkon Kasepuhan presenting an increase in the economy, powerful aura and guarding against threats and catastrophe.
\end{abstract}

Keywords: the Qur'an, amulet, verses of muhafazhah (preservation), living Qur'an

\section{Introduction}

The amulet is an object containing some writings and is believed to have some miracles: protecting its owner, preventing diseases and demons, as well as making its owner charismatic (pangabaran effect). Most of the Qur'an contain Qur'anic verses and are wrapped in a case. They are then worn as necklace, belt, or bracelet. The owner of amulet could also bring it in his/her pocket.

Amulet is part of cultural products exist in Indonesian Islamic society. In general, this factor differentiates Indonesian Muslims from Islamic community all over the world. One of them is the indigenous people Wewengkon Kasepuhan Lebak Banten with Muslim population of 1675,495 inhabitants (www.lebakkab.go_id-media- 
doc-post-cibeber-2014). However, the nature of the practices is syncretic culture, combining the elements of local beliefs and traditions (Humaeni, 2014: 61). These beliefs were already ingrained, especially on the Indigenous people Wewengkon Kasepuhan Lebak Banten and the communities of Banten Province in general (Irfani, 2011: 64). Even, Martin van Bruinessen states that Banten Province is one of the cultural centers that practice Magical theories or magical power taught directly by the shaman (Kyai), both in the muslim school and in the cloister.

This phenomenon is interesting to be examined further because the practices use the verses in the Qur'an used as an amulet to bring luck, blessing or salvation of life. This study aims to reveal the history of community belief in the amulets, ritual practices, and benefits of the amulets on the life of the Indigenous people Wewengkon Kasepuhan Lebak Banten. Whereas the category of the amulet will be examined only the amulets that apply verses in the Qur'an or Quranic alphabets.

The categories of this research is a field research using qualitative research method which constructs social reality or exploration, that is based by statement which is not necessarily proved (Moleong, 2007: 4). As this research approach (Gellner, 2002: 34) use anthropological approach and ethnography (Moleong, 2007: 25; Mulyana, 2010: 161).

\section{The Qur'an in the Life of Society}

Qur'anic studies in some community are usually stressed in the matter of Qur'an's function as guidance and mercy to human race, more over those who believe. But the function of Qur'an and Hadith can also benefit in many interests and contexts, whether for those believing or not.

There are some community practices in using the Qur'an in everyday life, as well as reading worship as well for other needs, among others:

- The Qur'an and Medicine

The treatment of diseases by using the verses of the Qur'an is the subject of one's degree to the Qur'an. A hadith narrated by Ibn Majah and Ibn Mas'ud which states that the Messenger of Allah. Said: "Use two (alternative) treatments, using honey and verses of the Qur'an."

- The Qur'an and the Power of Magic

The Qur'an is not only functioned as a guidance of life, but also as a magical power that provides safety and protection against black magic (teluh), invulnerability, pengasihan (a magic whereby a person is made to fall in love), pangabaran, and financial prosperity. Besides, its magical power refers to: amulet (an object believed to provide protection from dangers) and debus (invulnerability).

The Qur'an is not only used as a guide of life, the inauguration of certain surahs and certain verses of the Qur' an functioned as a magical power in order to be an antidote to black magic (salvation), salvation, sacrifice of sustenance, pack, mercy, and the charism high in the human eye. As for the magical powers in question, among others: the amulet (an object that has the power of antidote to danger) and debus (body science).

- The Qur'an and Customary Society

Muslims in Indonesia are not monolithic. They live in divergent traditions and religious practices expressing their various understandings to Islam.

There are several religious social rituals in the Banten community as well as selfdevelopment efforts to God, among others: rebo wekasan is a religious ritual of society in the form of prayers, bathing, reading shalawat, read certain verses and certain surahs (Haryanto, 2015: 44). This reading is done on the last Wednesday of 
Shafar month (Tihami, 1991: 1-5). Celebration Rebo Wekasan to be grateful for the blessings of Allah swt. Also to reject the various calamities (praying rejects dangers).

\section{Practical Indigenous Peoples Wewengkon Kasepuhan in the Use of Amulet}

The forms of Amulet

In the perception of the Indigenous Peoples of Wewengkon Kasepuhan Citorek, the amulets are objects that have a tuah / mana. The amulet they use various forms, the amulets are taken from the holy verses of the Qur'an until the pieces become Qur'anic alphabets, Particular and certain surahs of the Qur'an, kris, machetes, spears, knives, jangjawokan, za'faran oil, rings, incense, sepaheun (the current menu of stirring consisting of gambir, the gambir leaves stew which the water is evaporated, square round recipes, Used as a mixture of betel meal, apu, the lime that has been deposited for betel meal mixed with gambier, cardamom, cloves, and betel nut seeds), to turmeric panglai. Each will be explained as follows:

- Certain Verses and Certain Surahs of The Qur'an

The phenomenon that has been done by the Indigenous Peoples of Wewengkon Kasepuhan Citorek Lebak Banten in practicing the amulet of the holy verses of The Qur'an composed of Quranic alphabets and certain verses and surahs of the Qur'an in daily life, justified by the indigenous religious leaders Wewengkon Kasepuhan Kampung Babakan Cicurug Village Citorek Tengah, kyai Sarku.

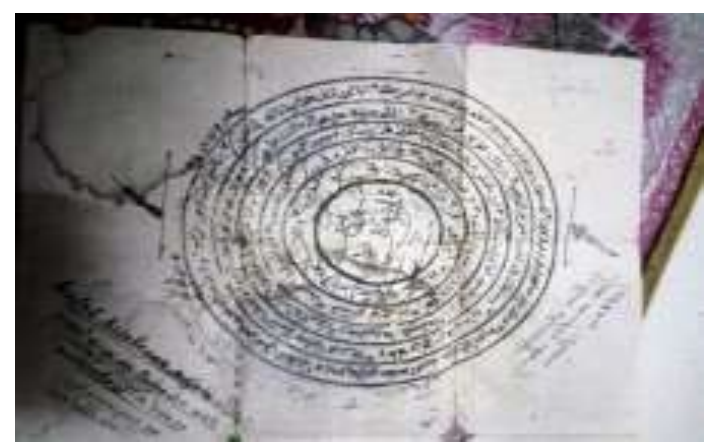

Picture 1: Amulet image that functions as an immune that is not susceptible to killed nor bullets.

The verses that are often used in the amulets are the verses about the preservation of God to his creatures or known as ayufa-muhafadzah (preservation) namely: Qs: al-Fātihhah: 1, Al- Baqarah: 255, Al-An ' Mm: 61, Hud: 57, Joseph: 64, Al-Ra'd: 11, Al-Ĥijr: 9, Al-Hijir: 17, Al-Anbyā: 32, As-Shāfāt: 7, Fushilat: 12, Huud: 57, Ash-Shurā: 6, Al-Infithār: 10-12, At-Thāariq: 4, and al-Burūj: 12-22.

- Huruf Hijaiyyah (Qur'anic alphabets)

In the wafaq amulet there are Arabic numbers, names of angels, names of Khulafaur Rashidin to Quranic alphabets such as lafaz alif, ba, ta, tsa, jim, ha, kha, dal, dzal, ra, zay, sin , Shin, shad, dhad, tha, lam, mim, nun until others (Rachman, 2010: $17 \& 22$ ). Besides the single hijaiyah, there is also fawath al-suwar in the form of almuqatha'ah (يس, حم عسق, كهيعص, ن). 


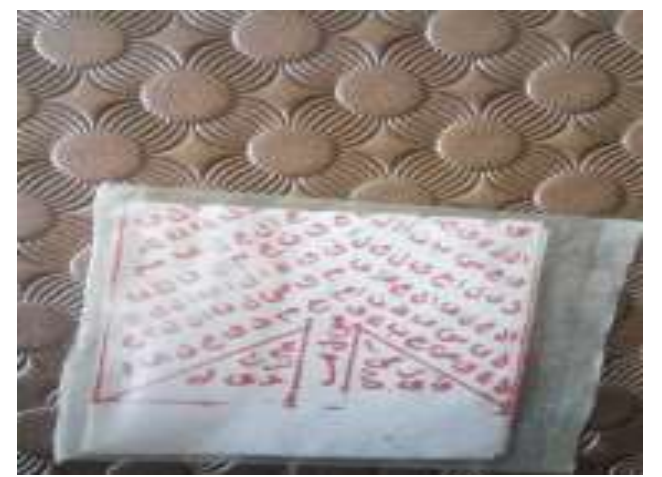

Picture 2: Wafaq Amulet made of paper, for mercantile buying and selling (trading). (Private Doc Source)

- The amulet without verses of the Qur'an

As for amulet or magic items in perspective kaolotan Adat Wewengkon Kasepuhan Citorek, which is shaped like, rice field tangtu, kris, spear, knife, hihid, dulang, pangarih, sepaheun, incense, and panglai. These items are objects that are closely related to the family equipment and farming rice, both in rice fields and in huma (plantation). They get it through the descendants of the old-fashioned stereotypical paratraces that must be resumed in the struggle.

Discontinuing the struggle means pamali to indigenous community of Wewengkon Kasepuhan Citorek and leads to suffering.

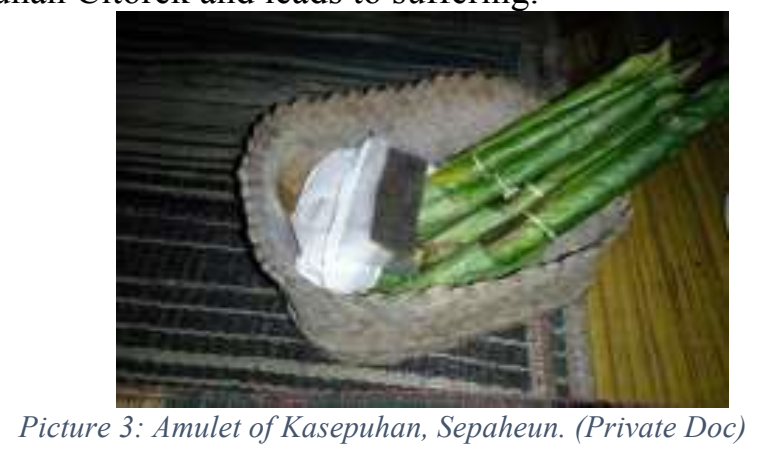

\section{The Benefits of Wearing Amulet}

Wewengkon indigenous people believe there are many benefits of using amulets according to the guidance of the teacher, namely:

\section{- Helper / Squeezer}

The practices they have done, the benefits have been felt by the Indigenous Peoples Wewengkon Kasepuhan Kampung Guradog Barat Citorek Timur Village, Syria. He attaches wafaq (pieces of the holy verse of the Qur'an) on the doorstep of the shop and puts it in a wallet. This belief in the power of the amulet made his business smooth and in demand.

\section{- Pangabaran / Charismatics}

Charismatic / charismatic charisma is usually used by certain public figures, such as political figures, religious leaders, and traditional leaders of Kasepuhan. But, ordinary citizens are not a few who wear it. This practice is no longer the secret of Wewengkon Kasepuhan Citorek Indigenous people.

- Rescue of Soul and Body

The influence of The Qur'an amulets is felt directly by Indigenous Peoples Wewengkon Kasepuhan Kampung Cibengkung Village Citorek Barat, by Saridan. When he was cornered by the threat of murder from all the influential champions in the Indigenous people of Wewengkon Kasepuhan Citorek. For his belief in the amulet he 
used as if the previous ruthless champion or have the hard nature without mercy to human beings become ordinary as normal once- Will be no problem (Results of in-depth interviews with Saridan indigenous peoples Kasepuhan Kampung Cibengkung Citorek Barat Village on 20 April 2017).

- Healer

Amateur The Qur'an can also be used as a healer of disease (Q. 17: 82). According to the religious leaders of Indigenous Peoples Wewengkon Kasepuhan Kampung Babakan Cicurug Village Citorek Tengah, Kyai Sarku, if there is someone who is affected by the disease does not quickly recover. In fact, people who have the disease had been treated through medical to various hospitals, then according to him, the last solution is the treatment through alphabets of the Qur'an (In-depth interview with the indigenous religious leaders Wewengkon Kasepuhan Kampung Babakan Cicurug Village Citorek Tengah, Kyai Sarku when the confirmation of data on 02 July 2017).

\section{The Use of Amulet on Indigenous Peoples Wewengkon Kasepuhan}

There are various ways to use the amulet, namely:

- Attaching Charms to the Door and Wardrobe Sections

According to Indigenous Peoples Wewengkon Kasepuhan Village Citorek Sabrang, Mrs. Tiamah, the amulet that he used must be affixed in the doorway and made home decoration in the guest room.

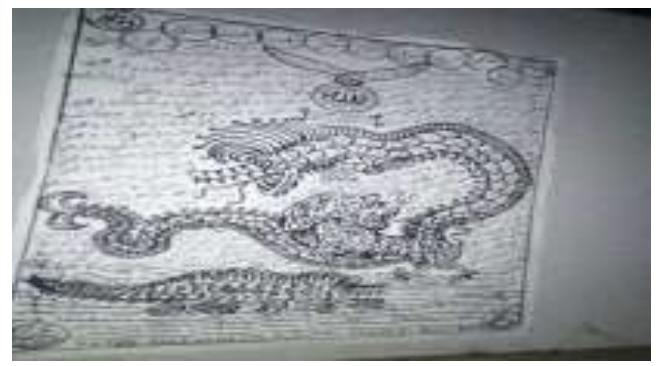

Picture 4:Amulet wafaq safety that is attached to the doorstep and made wall decoration of the house.

\section{Wearing Amulet on the Belt}

Indigenous Peoples Wewengkon Kasepuhan Jaro / Village Chief of Citorek Sabrang, Jaro Asid Rosidin never felt the strangeness beyond human reason, that is when trying and practicing the amulet of The Qur'an (wafaq) a belt is not susceptible to be killed.

In the subconscious, amulet has an efficacy to make confidence and courage before anyone.

\section{Put the Amulet in the Wallet}

Amulet worn in his wallet usually to get a high charisma, immunity, lover, and to get rich. However, these mystical practices were carried out by Supriati Wewengkon Kasepuhan Indigenous Peoples Cicurug Village Citorek Tengah Village in terms of trading shop.

\section{Mixing the Amulet into the Oil}

Small-sized Qur'an alphabets are mixed into fragrant oil, which is a sweet, sweet fragrance that smells evenly. It is practiced indigenous people Wewengkon Kasepuhan Kampung Babakan Rice Village Citorek Sabrang, Sarnata every time want to sell 
always wear oil that has been mixed with the holy verses of the Qur'an in the form of wafaq.

\section{Conclusion}

The main conclusions of this research are: firstly, the existence of the belief of Indigenous people Wewengkon Kasepuh to amulet is originated from belief to kasepuhan or people that respected who ordered the use of amulets in daily life. Secondly, the verses written in the amulet are the verses muhafadzah (preservation), Quranic alphabets; Third, amulets are used in wallets, belts, necklaces, bracelets and doors of the house. Fourth, indigenous people Wewengkon Kasepuhan directly feel the benefits of amulets that is in the presence of an increase in the economy, authority and guarding against threats and calamities.

Unbelief of the strength of amulets and disobedience to the elders will bring the catastrophe of life. This ritual must be maintained by their descendants. If it is not continued, the Wewengkon Kasepuhan Citorek Adat community will get pamali (sin) which is negative.

\section{References}

Abdurrahman and friend, Romdon. ed., 1993. Religion, and Society. Yogyakarta: IAIN Sunan Kalijaga Press.

Abu Tolib, Nurdeen Deuraseh and Mansor. 2005. "Mentality Health in Islamic Medical Tradition", The International Medical Journal, Volume 4, No. 2.

Adriana, Iswah. 2011. "Neloni, Mitoni or Tingkeban: (The Comparasion between Java Tradition and Muslim Council's Reality)", KARSA, Volume 19, No. 2.

Agus, Bustanuddin. 2006. Religion In Mankind Life, Interference of Religion Antropology. Jakarta: PT Rajagrafindo Persada.

Ali, Muhamad. 2005. "Teks Studies, Living Qur'an and Living Hadith Studies "Journal of Qur'an and Hadis Studies-Vol. 4, No, 2.

Andriawan, Didik. 2013. “The Using The Qur'an Verses as Cure (Studi Living Qur'an to Medical Treathment Dr. K.H. Komari Saefulloh in Sunan Kalijaga Cottage, Pakuncen Village, Patianrowo Distric, Nganjuk Residence)", Under Graduate Thesis Major of The Qur'an Exegesis and Hadith Studies, Ushuluddin Faculty, UIN Sunan Kalijaga Yogyakarta

Central Statistic Departement of Lebak-Banten, Kecamatan Cibeber in The Event Of Cibeber District In Figures 2014: Geografic Condition and wealth, accesed on 15 September 2016 from www.lebakkab.go .id-media-doc-post-cibeber-2014.

Bowie, Fiona. 2001. The Anthropology of Religion. Oxford: Blackwell Publishers.

Chalik, Abdul. 2016. "Religion and Politic in Tradition Rebo Wekasan Festival", Ibda' Journal Kebudayaan Islam, Volume 14, Nomor 1.

Djajadiningrat, Hossen. 1983. Critical Studies About Banten's Historical. Jakarta: Djambatan.

Esack, Farid. 2008. Samudera The Qur'an, terjemahan Nuril Hidayah. Yogyakarta: Diva Press.

F Nagamia, Husain. 2003. "Islamic Medicine History and Current Practices", ed., Aysegül Demirhan Erdemir and Abdul Nasser Kaadin, Journal of the International Society for the History of Islamic Medicine (ISSN: 1303-667x), Volume 2, Nomor 4.

Ghazal, Sharif Kaf. 2003 "Islamic Medicine History and Current Practices", ed., Aysegü1 Demirhan Erdemir and Abdul Nasser Kaadin, Journal of the International Society for the History of Islamic Medicine (ISSN: 1303-667x), Volume 2, Nomor 
4.

Ghazali, Imam Abu Hamid. 2002. Tafsir Ayat Cahaya dan Telaah Kritis Pakar, terjemahan Hasan Abrori dan Mashur Abadi. Surabaya: Pustaka Progresif. Irfani, Fahmi. 2011. Jawara Banten: Sebuah Kajian Sosial, Politik dan Budaya. Jakarta: Young Proressive Muslim Press.

Moleong, Lexy J. 2007. Metode Penelitian Kualitatif. Bandung: PT Rosda Karya. 